\title{
THE IMPACT OF A RECENT NATURAL DISASTER ON THE JAPANESE FINANCIAL MARKETS: EMPIRICAL EVIDENCE
}

\author{
- Bachar Fakhry, Bora Aktan, Omar Masood, Manuela Tvaronavičiene, \\ Saban Celik
}

\begin{abstract}
The devastating Japan earthquake (magnitude 9.0) and tsunami (39-metre high) of 2011, also called the Great Tohoku or Sendai earthquake, was a record-breaker natural disaster causing enormous damage and a nuclear meltdown at Fukushima nuclear power plant. This paper attempts to analyse the long and short run effects of this record-breaking natural disaster on the Japanese equity, debt and FX markets as well as Gold as one of the most popular metals and investment options, using daily data. A variance bound test proposed by Fakhry \& Richter (2018) underpinned by the C-GARCH-t model of volatility is adopted. The results seem to indicate that the natural disaster influenced the efficiency of the market in the immediate terms more than the long term. In a global financial market where the key is competitiveness, it is essential to analyse the efficiency and therefore stability of the Japanese financial market. Therefore, analysing the impact of the natural disaster on the competitiveness of the Japanese financial market.
\end{abstract}

Keywords: Financial Markets, Natural Disasters, Japan, EMH, Volatility tests

JEL Classification: C12, C58, D81, G14, G15, Q54

\section{INTRODUCTION}

The question of what moves markets have been debated for ages (Mentel et al., 2016; Zemlickiene et al. 2017; Michailova et al., 2017; Masood et al., 2017; Peker et al. 2017; Ahmed et al. 2018; Abbas, 2018; Jankelová et al., 2018; Fernández et al., 2018; Veselovsky et al., 2018). The main issue is that the movement in the markets is a result of the pricing of information, the efficient market hypothesis advocated by Malkiel (1962) and Fama (1965), or the reaction of the market participants to the information, behavioural finance theory advocated by Statman (2008) and Subrahmanyam (2007) amongst others. Conversely, the key to understanding financial market fluctuations in any event lay in the reactions of the market participants and not the events themselves as hinted by Bernard Baruch (Lee et al., 2002). With this in mind, we analyse the impact from the Tohoku earthquake on the long and short run volatility and efficiency of the Japanese financial market.

On 11 March 2011, the Tohoku earthquake hit Japan's north-eastern coast, the following overwhelming tsunami and near catastrophic nuclear power station disaster devastated Japan. The Japanese financial market is regarded as the second largest globally behind the US. Its equity market was estimated to be worth $\$ 4.995$ trillion at the end of 2016 according to statistics from the World Bank, making it the second largest market to the US. The sovereign debt market was 
worth $\$ 8.93$ trillion at the end of 2016 according to the Federal Reserve Bank of St. Louis, second only to the US market. The average total daily turnover on the yen-based FX market was estimated to be \$1.096trillion in April 2016 according to the Bank for International Settlements, with the introduction of the Euro in 1999 the Yen based FX market is now the third largest. According to the World Gold Council, Japan has the world's ninth largest gold reserve with a total of 765.2 tons. And although this only represents a mere $2.4 \%$ of its total asset reserve, yet it is a large capacity of gold reserves. Hence it is important to understand the impact of the earthquake on the Japanese financial market in the short and long run.

In this paper, we take a new look at the issue through the movement in the Japanese financial market with respect to the Tohoku earthquake. Since as hinted by Engle \& Lee (1999), De Bondt (2000) and Pastor \& Stambaugh (2012); conventional wisdom dictates, there is a difference between short and long runs. Essentially, the reaction of market participants tends to deviate with time. Hence, we use the variance bound test proposed by Fakhry \& Richter (2018) using the Asymmetrical Component GARCH model to analyse the impact from the earthquake on the long and short run volatility and efficiency of the Japanese financial markets.

There were previous papers and research on the impact of the earthquake on the financial market (Asongu, 2012; Luo, 2012; Ferreira \& Karali, 2015). The majority of those are restricted to the equity market. We use the four major financial asset markets in Japan: Equity, FX, Gold and Sovereign Debt. We also analyse the efficiency and volatility over three different observations, the immediate period after (11/03/2011-31/12/2012) the earthquake. The other two observations are extended to include the whole picture before (the observed dataset starts on $31 / 12 / 1997$, however, due to circumstances we could not get the full data for the sovereign debt market which starts on 31/03/2004. The end date is the same for all 10/03/2011.) and after (11/03/2011-31/12/2016) the earthquake. As far as we know, the asymmetrical C-GARCH model has not been used to analyse the long and short run effect of any natural disaster on the financial markets.

In general, the findings, with a few exceptions, seem to be accepting the consensus that the earthquake did not have a changing impact on the financial market. The statistics show that the Japanese financial market in general is inefficient. The conclusion is that in general the Japanese financial market is reactive rather than efficient meaning that the reaction of the market participants moves the price more than the information.

This paper is structured as follows. Section 2 briefly and critically reviews the previous studies and statistics about the impact of the Tohoku earthquake over the economy and more importantly on the financial markets. Section 3 presents the methodology. Section 4 presents the data while Section 5 discusses empirical results. Finally, Section 6 concludes.

\section{THEORETICAL BACKGROUND}

This brief review is a combination of key sections: a review of the literature on the impact of earthquakes on the economy and more importantly the financial markets. The second is a review on the statistical impact of the Tohoku earthquake on the Japanese financial market. 
There have been many papers written about the Tohoku earthquake and the following tsunami (Clemente, 2011; Lay \& Kanamori, 2011; Mimura et al. 2011; Mori et al. 20111; Sato et al. 2011). Here is a summary of the earthquake and ensuing tsunami. According to Mori et al. (2011), at 14:46 JST on 11th March 2011, a large earthquake hit the north-east Japan just offshore from Tohoku. Measuring at 9.0 on the Richter scale, the earthquake was powerful but what made it worst is that it was a megathrust category earthquake which raptured along $450 \mathrm{~km}$ by $250 \mathrm{~km}$ according to Mori et al. (2011). The problem is that a megathrust earthquake in general generate large displacement of land; according to Sato et al. (2011) the Tohoku earthquake shifted the coast of Japan up to $5 \mathrm{~m}$ eastwards lifting the seabed by $5 \mathrm{~m}$. The displacement was as large as 60 to $80 \mathrm{~m}$ nearer the subduction, the largest ever displacement by an earthquake as stated by Lay \& Kanamori (2011). Thus, generating an energy level of 100 megatons and resulting in quickening the earth rotation on its axis (Lay \& Kanamori, 2011; Clemente, 2011). According to Mori et al. (2011) and Mimura et al. (2011), the resulting tsunami reached heights of at least 39m and inundated over $400 \mathrm{~km} 2$ of land causing 15,641 fatalities with a further 5,007 missing as of 27th July 2011. The sad truth is that there was a defensive wall along the coast which should have been enough to protect much of the coastal land from the tsunami, however, due to the land displacement the wall sunk by approximately 1 metre. This had the add-on effect of endangering the Fukushima nuclear power station and causing the worst nuclear energy crisis since Chernobyl in 1986, according to Asongu (2012).

According to Ferreira \& Karali (2015), the damage from the Tohoku earthquake was estimated at \$211billions. The statistics obtained from the Federal Reserve Bank of St. Louis point to the Japanese economy sinking by approximately 15 trillion yens or 3\% of GDP during the two quarters between quarter 42010 and quarter 2 2011. The same period saw an increase in debt of approximately 53.8 trillion yens and a decrease in consumption of approximately 2.6 trillion yens. The production index fell from 100.6 to 93 . These statistics illustrates the damage to the economy in the aftermath of the Tohoku earthquake.

Recent empirical evidence concerning the impact of natural disasters on financial markets is mainly in the equity market and paints a mixed picture. Worthington \& Valadkhani (2004) found that a market participant in the Australian equity market reacted differently to different types of natural disasters. Barton (2005) found market participants in US equity markets reacted positively in the aftermath of several major hurricanes attacks in the US. Worthington (2008) found that natural disasters have no significant impact on the returns in the Australian equity market. Wang (2011) found that Japanese natural disasters do have an indirect impact on the volatility of stock markets' returns in the US and Japan. However, Maierhofer (2011) found that market participants' reactions on stock markets in the immediate aftermath of the five worst natural disasters exhibited signs of panic selling. Parker \& Steenkamp (2012) found that the Christchurch earthquakes of 2010 and 2011 had little impact on the financial institutions in New Zealand.

Ferreira \& Karali (2015) found little impact in general from earthquakes on international financial markets suggesting they are resilient to these natural disasters. However, Ferreira \& Karali (2015) did find some impact on the Japanese financial market suggesting the volatility of the stock market does increase. And as evidenced by Luo (2012), in the immediate aftermath of the 
Tohoku earthquake, the Nikkei closed down 6.18\%. The major global stock markets all closed down with the US market closing approximately $6 \%$ down, the UK market down $1 \%$, the German market down $1.3 \%$ and Hong Kong down 1.6\%. Thus hinting at market participants reacting to the earthquake. In Asongu (2012), there were mixed results in the transmission of volatility in the global FX and equity markets after the Tohoku earthquake. This has two significant factors: the first is that markets react to natural disasters differently depending on their status and sovereign economic relationship. However, the key factor raised by Asongu (2012) is that transmission in volatility on the global financial market is not limited to financial or economic crises. Natural disasters can and often do transmits volatility in the global financial market for certain periods.

\section{RESEARCH OBJECTIVE AND METHODOLOGY}

The main aim of this paper is to analyse the impact of the Tohoku earthquake on the efficiency of the markets in the long and short runs. We use the variance bound test proposed by Fakhry \& Richter (2018) using an asymmetrical C-GARCH, proposed by Engle \& Lee (1999). We use the $5 \%$ critical value F-statistics to test the efficient market hypothesis. We also follow the prerequisite steps advocated by Shiller $(1979,1981)$.

- As with Shiller (1981a), we calculate the datasets in our test as a time varying lagged variance of the price using equation 1 and a 5-lagged system.

$$
\lim _{t \rightarrow T} \operatorname{var}\left(\text { Price }_{t}\right)=\frac{\sum_{q=1}^{Q}(\text { Price }-\mu)^{2}}{Q}
$$

- The residuals are estimated using a first order autoregressive model as illustrated by equation 2 and 3.

$$
\begin{aligned}
& \operatorname{var}\left(\operatorname{Price}_{t}\right)=a+b_{1} \operatorname{var}\left(\operatorname{Price}_{t-1}\right)+\mu_{t} \\
& \mu_{t}=\tau \mu_{t-1}+\varepsilon_{t}
\end{aligned}
$$

The GARCH model as intended by Bollerslev (1986) is equation 4

$$
h_{t}=\omega+a_{p} k_{t-1}+\beta_{q} h_{t-1}
$$

As suggested by Engle \& Lee (1999), equation 4 may be rewritten as equation 5 where the dynamics of the structure of conditional variance can be illustrated.

$$
h_{t}=\sigma^{2}+\left(a_{p} k_{t-1}-\sigma^{2}\right)+\left(\beta_{q} h_{t-1}-\sigma^{2}\right)
$$

However, as argued by Engle \& Lee (1999), at the heart of this equation is the question of whether the long run volatility is unconditional. Surely, a more flexible specification where the long run volatility is allowed to evolve slowly autoregressively is a more realistic model of volatility, given the empirical evidence on volatility as argued by Engle \& Lee (1999). A more flexible model would be equation 6 where $\sigma 2$ is represented by $\mathrm{m}_{-} \mathrm{t}$, a time varying long run model of volatility.

$$
\begin{aligned}
& m_{t}=\omega+\varrho m_{t-1}+\varphi\left(k_{t-1}-h_{t-1}\right) \\
& \left(h_{\mathrm{t}}-\mathrm{m}_{\mathrm{t}}\right)=\sigma^{2}+\left(\alpha_{\mathrm{p}} \mathrm{k}_{\mathrm{t}-1}-\mathrm{m}_{\mathrm{t}-1}\right)+\left(\beta_{\mathrm{q}} \mathrm{h}_{\mathrm{t}-1}-\mathrm{m}_{\mathrm{t}-1}\right)(7)
\end{aligned}
$$


Hence, equation 6 is s stochastic representative on of the long run volatility, also known as the trend in volatility, and equation 7 is the difference between the conditional volatility and trend, i.e. the long run volatility. Essentially, equation 7 is the short run or transitory volatility.

We use a single asymmetrical order one lagged C-GARCH model in our tests using a TARCH as proposed by Zakoian (1994) given by equation 8. Combining equation 7 and 8 and subtracting $m \_t$ from the asymmetrical factor, we get equation 9. A key factor is that the asymmetrical effect is only added to the short run component of the C-GARCH model. This is mainly due to the short life of the asymmetrical effect.

$$
\begin{aligned}
& h_{t}=\alpha k_{t-1}+\beta h_{t-1}+\gamma k_{t-1} I \\
& \left(h_{t}-m_{t}\right)=\sigma^{2}+\left(\alpha_{p} k_{t-1}-m_{t-1}\right)+\left(\beta_{q} h_{t-1}-m_{t-1}\right)+\gamma\left(k_{t-1}-m_{t-1}\right) I \\
& \text { Where } I= \begin{cases}0, & \varepsilon_{t} \geq 0 \\
1, & \varepsilon_{t}<0\end{cases}
\end{aligned}
$$

The key is the $\gamma$ coefficient in equation 9 where positive then it is regarded as an asymmetrical effect; whereas a negative $\gamma>0$ hints at a leverage effect meaning negative shocks have a greater impact than positive shocks.

We use Engle \& Patton (2001) definitions to analyse the coefficients of the volatility model. As with Fakhry \& Richter 2018, we analyse both the long and short run coefficients of the Component-GARCH model.

We calculate our test statistics using equation 10 and 11 as the short run and long run tests of efficiency respectively. We set the F-statistics to 1,96 .

$$
\begin{aligned}
& \text { EMH Test }_{S R}=\frac{(\alpha+\beta+\gamma)-1}{\text { standard deviation }(\operatorname{var}(x))} \leq F \text { statistics } \\
& \text { EMH Test }_{l R}=\frac{(\rho+\Phi)-1}{\text { standard deviation }(\operatorname{var}(x))} \leq F \text { statistics }
\end{aligned}
$$

By definition the market is efficient when the conditions as set in equations 10 and 11 are true. Hence, we reject the null hypothesis for the EMH if the condition in equations are true but accept the null hypothesis of the market being too volatile to be efficient for anything else.

\section{DATA DESCRIPTION}

We use four major Japanese financial markets, as illustrated in Table 1 to analyse the impact of the 2011 Tohoku earthquake and tsunami on the efficiency of the financial markets. As with the norm, we choose to use a five-day week filling in the missing data with the last known price.

Tab. 1 - Major Japanese Financial Markets Indices

\begin{tabular}{|l|l|l|l|l|}
\hline Market & Equity & Gold & Foreign Exchange & Sovereign Debt \\
\hline Index & Nikkei 225 & & $\begin{array}{l}\text { Effective } \\
\text { Exchange Rate } \\
\text { index, Yen }\end{array}$ & $\begin{array}{l}\text { Japan All Maturities In- } \\
\text { dex (Inflation-Linked) }\end{array}$ \\
\hline
\end{tabular}




\begin{tabular}{|l|l|l|l|l|}
\hline Source & investing.com & $\begin{array}{l}\text { World Gold } \\
\text { Council }\end{array}$ & Bank of England & $\begin{array}{l}\text { Barclays Risk Analytics } \\
\text { \& Index Solutions Ltd * }\end{array}$ \\
\hline Period & $31 / 12 / 1997-31 / 12.2016$ & $\begin{array}{l}31 / 03 / 2004- \\
31 / 12 / 2016\end{array}$ \\
\hline Observations & 4958 & 3,328 \\
\hline
\end{tabular}

* As of 24th August 2016, the product is known as Bloomberg Government bonds

The four indices are based on various weighted ratios of the component price:

- Nikkei 225 consist of 225 of the largest listed companies on the Japanese equity market each weighted by a given ratio.

- Yen Currency Index (See the following Bank of England website for information: http:// www.bankofengland.co.uk/statistics/pages/iadb/notesiadb/Effective_exc.aspx) consists of five major currencies with a weighted ratio: US Dollar, British Sterling, Euro, Swiss Franc and Swedish Krona.

- Japanese All Maturities Government Inflation-Linked Index consists of all the government bonds maturities weighted by a ratio.

- Gold market index is the price of gold weighted by the 3-year GDP in US \$.

A key issue with our variance bound test was the standard deviation of the gold, Nikkei 225 and Yen FX indices which caused a problem with the EMH test statistics. The solution was to divide the daily index price by 100 for the equity and 10 for the gold and FX before calculating the five-day variance.

\section{RESULTS AND DISCUSSION}

As hinted earlier, the keys to the EMH test statistics are the coefficients to the variance equation of the volatility model and standard deviation of the observed dataset. Hence in essence the model of volatility estimated determines the statistics. Unlike previous studies, we use the asymmetrical C-GARCH model in this paper to analyse the effect of long and short runs on EMH.

We used the Marquandt estimation method for all estimations. However, we used the best error distribution model in our estimations as illustrated in Tab. 2. For all other options, we used the default settings. Crucially, our system is running E-views 9.5 on a Windows 10 Pro computer with a 10 cores CPU and 32 Gigabytes RAM.

Key behavioural theories dictate that market participants react with greater intensity to news in the short run as hinted by Engle \& Lee (1999). However, as illustrated in Table 2, the evidence seems to be hinting at a mixed reactive behaviour with only five short run observations out of twelve holding the theory. This would suggest the Japanese market is highly reactive both in the long and short runs. An interesting finding is in nine of the observations the Japanese market hints at a negative asymmetrical effect, a key observation in the market pointing towards negative movements having greater influence than positive movement of similar magnitude on the volatility as stated by Black (1976). 


\subsection{The Pre-Earthquake Period}

The mixed picture in the Japanese financial market during the pre-earthquake period could be explained by looking at the observed period. During the early parts of the observed period, Japan was dealing with the aftermath of a financial crisis and economic stagnation from the mid to late-1990s, (Nakaso, 2001; Hoshi \& Kashyap, 2004; Harari, 2013). Towards the end of this observed period, the onslaught of the global financial crisis and the following economics recession came and Japan was not immune from this global crisis. These two periods of uncertainty may have affected our estimation models. Although as Kawai \& Takagi (2009) hints, the global financial crisis did not directly impact the Japanese financial market; yet as hinted by Kawai \& Takagi (2009) due mainly to the intertwined nature of the global financial system and a strong dependency on exporting, both the global financial crisis and recession did have a strong impact on the Japanese economy and hence market participants. So, in essence this observational period was marked by the reactions of the Japanese market participants during the aftermath of the Japanese financial crisis and onslaught of the global financial crisis at each end of the observed period.

The $\varrho$ coefficient in Tab. 2 hints at the pre-earthquake period with the exception of the equity market, the remaining three markets hint at high persistent in the long run. The equity market seems to be pointing at low persistent in the aftermath of a shock. Except for the FX market, the high $\phi$ coefficient seems to be suggesting a highly reactive financial market in the long run. The low $\phi$ coefficient of the FX market bucks the trend in the Japanese financial market. So, in truth both the market shock and persistent coefficients in the long run do paint a mixed picture during the pre-earthquake period.

The short-run observation points to a mixed persistency picture with both the SD and FX markets displaying the insignificantly low $\beta$ coefficient. The equity market points to a low level of persistent in the aftermath of a shock to the market, while the gold market has a high persistency in the aftermath of a shock. Conversely, the $\alpha$ coefficient dictates that both the FX and equity markets were very reactive, in fact the FX market experienced a significantly high market shock coefficient. While the gold market had a low market shock reaction. However, the SD market experienced near zero market shock reactivity. The $\gamma$ coefficient illustrates a more solid picture; with the exception of the SD market, the Japanese financial market was demonstrating a negative asymmetrical effect. The SD market illustrates a positive asymmetrical effect.

Interestingly, according to Tab. 2, this mixture of results in the volatility points to a two-way split with respect to the efficiency of the Japanese market during the pre-earthquake period. The SD, Gold and Equity markets are efficient in the long and short runs. However, the FX market seems to be accepting the null hypothesis of the market being too volatile to be efficient in both the long and short runs.

To understand the different efficiency status and thus reactions, we need to remember as noted earlier this period was sandwiched between two financial crises and deep economic downturns. The reactions of the Japanese market participants to both financial crises made the financial market very unstable and volatile, however, the statistics hints at the SD, Gold and Equity markets accepting the EMH. It must be remembered that as pointed by Kawai \& Takagi (2009), for a long period in the mid-2000s, the Japanese financial market was steadily growing, and the 
economy was stabilizing. As hinted by Fakhry (2016), a possible explanation could be find in the overreaction/underreaction stability status where an observed market exhibiting both high and low volatile periods during an observational period could give the appearance of an efficient market. Therefore, the SD, Gold and Equity markets acceptance of the efficient market hypothesis during the pre-earthquake observation could be due to the overreaction during certain periods being cancelled out by the underreaction during other periods of the observation.

It must be noted that the yen is regarded by many as a safe haven, this is the key to understanding the results in the FX market. As hinted by Fakhry \& Richter (2016), this has the effect of shifting the market efficiency usually to an inefficient status. This is true especially during a crisis like the global financial crisis where due to the difficulties in the US and Europe, as dictated by the behavioural finance theory, many saw the yen as a safe haven. This leads to demand outstripping supply and hence the equilibrium price is constantly shifting. Therefore, the market cannot be efficient.

\subsection{Post-Earthquake Period}

The observed period in the aftermath of the Tohoku earthquake and the following tsunami saw a number of events highlighting the behaviour of the Japanese financial market participants. And while each event on its own is enough to change the trend in the behaviour of market participants, yet the damage to the Japanese economy served up by the earthquake and the following tsunami must have heightened the impact of these events. Of course, the on-going sovereign debt crisis and economic downturn in the Eurozone and US played a major role. Since the Japanese financial market is often seen as a safe haven against the Eurozone and US markets, it is believed this may have slightly affected our estimation results. However, the real impact on our estimation results may have come from the heightening in tensions with the Chinese over the Senkaku Islands and the North Korean nuclear threat. The rise of China as a global and economic power meant that China is able to claim its rights on the islands. This led to increase tensions between the two powers of eastern Asia. The problem is that this leads to uncertainty in the financial markets. So, every time there is a flashpoint in the relationship between China and Japan, the market participants react. The second issue is the nuclear threat from North Korea. This was probably caused by the instability and isolation of the North Korean regime. These two act as a counter behaviour to the safe haven prospects of the Japanese financial market. When added to the impact of the Tohoku earthquake on the Japanese economy, the results produced an increasingly uncertain financial market.

The high $\varrho$ coefficient in the long run in Table 2 throughout the Japanese financial market is a sign of long-lived issues. The significantly high persistent of the SD market in the long run illustrates the underlying issues concerning the size of the sovereign debt of Japan. The key point to understand here is that the $\phi$ coefficient of the SD market in the long run is relatively low hinting at low market participants' reaction to market shocks. Conversely, in contrast to the SD market, the $\phi$ coefficient of the FX, Gold and equity markets seem to be suggesting a high reaction to market shocks by market participants. 
Tab. 2a - Statistics for Asymmetrical C-GARCH model

\begin{tabular}{|c|c|c|c|c|c|c|c|c|c|c|c|c|}
\hline 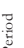 & \multicolumn{4}{|c|}{$\begin{array}{c}\text { Pre-earthquake } \\
31 / 12 / 1997-10 / 03 / 2011\end{array}$} & \multicolumn{4}{|c|}{ Post-earthquake 11/03/2011-31/12/2016 } & \multicolumn{4}{|c|}{$\begin{array}{l}\text { Immediate post-earthquake } \\
11 / 03 / 2011--31 / 12 / 2012\end{array}$} \\
\hline 苛 & $\mathrm{SD}^{*}$ & $\mathrm{FX}$ & Equity & Gold & SD & $\mathrm{FX}$ & Equity & Gold & SD & $\mathrm{FX}$ & Equity & Gold \\
\hline t. & Student $t$ & Normal & Normal & Normal & GED & Student $\mathrm{t}$ & GED & Normal & Student $\mathrm{t}$ & Normal & GED & Student $t$ \\
\hline \multicolumn{13}{|c|}{ Mean } \\
\hline \multirow[t]{2}{*}{ a } & $2.26 \mathrm{E}-02$ & $1.47 \mathrm{E}-03$ & $6.67 \mathrm{E}-03$ & $1.22 \mathrm{E}-02$ & $4.48 \mathrm{E}-03$ & $1.75 \mathrm{E}-03$ & $9.95 \mathrm{E}-03$ & $3.07 \mathrm{E}-02$ & $1.79 \mathrm{E}-03$ & $2.46 \mathrm{E}-03$ & $2.76 \mathrm{E}-03$ & $5.25 \mathrm{E}-02$ \\
\hline & (1.85E-04) & (1.11E-05) & (5.80E-05) & $(1.29 \mathrm{E}-04)$ & (7.11E-06) & (1.29E-05) & (3.70E-05) & (2.01E-04) & $(2.04 \mathrm{E}-05)$ & (5.41E-05) & (5.53E-05) & $(1.02 \mathrm{E}-03)$ \\
\hline \multirow[t]{2}{*}{ b } & 0.91513 & 0.91263 & 0.86178 & 0.88970 & 0.89737 & 0.84657 & 0.79788 & 0.90699 & 0.886492 & 0.805181 & 0.875935 & 0.81937 \\
\hline & (2.23E-03) & (3.19E-04) & $(6.93 \mathrm{E}-04)$ & (1.06E-03) & (1.42E-03) & $(2.26 \mathrm{E}-03)$ & (1.95E-03) & (8.90E-04) & (3.31E-03) & $(1.56 \mathrm{E}-03)$ & $(4.65 \mathrm{E}-03)$ & $(4.42 \mathrm{E}-03)$ \\
\hline \multirow[t]{2}{*}{$\mu$} & 1.00429 & 1.04534 & 1.01905 & 1.03104 & 1.08476 & 1.01687 & 1.00054 & 1.08664 & 1.035004 & 1.042105 & 1.018909 & 1.01549 \\
\hline & (2.62E-03) & (1.36E-04) & (3.11E-04) & (7.39E-04) & (1.27E-03) & $(2.57 \mathrm{E}-03)$ & $(5.45 \mathrm{E}-04)$ & $(4.90 \mathrm{E}-04)$ & $(3.24 \mathrm{E}-0.3)$ & (2.05E-03) & $(4.51 \mathrm{E}-03)$ & $(4.78 \mathrm{E}-03)$ \\
\hline \multicolumn{13}{|c|}{ Variance } \\
\hline \multirow[t]{2}{*}{$\omega$} & $2.371 \mathrm{E}-03$ & 1.010E-05 & $2.280 \mathrm{E}-04$ & $8.370 \mathrm{E}-05$ & $2.180 \mathrm{E}-05$ & $3.140 \mathrm{E}-04$ & $1.000 \mathrm{E}-04$ & $6.495 \mathrm{E}-03$ & $1.19 \mathrm{E}-02$ & $6.63 \mathrm{E}-06$ & 4.48E-06 & 1.689E-03 \\
\hline & $(1.99 \mathrm{E}-02)$ & (5.41E-06) & $(1.54 \mathrm{E}-05)$ & $(3.83 \mathrm{E}-06)$ & (3.76E-05) & $(1.53 \mathrm{E}-03)$ & (2.40E-04) & (1.13E-03) & $(1.15 \mathrm{E}-02)$ & (3.46E-06) & (1.48E-06) & (2.21E-03) \\
\hline \multicolumn{13}{|c|}{ Long-run } \\
\hline \multirow[t]{2}{*}{ e } & 0.99219 & 0.99821 & 0.84704 & 0.95786 & 1.00021 & 0.99994 & 0.99379 & 0.91678 & 0.999996 & 0.926033 & 0.749443 & 0.96477 \\
\hline & $(6.53 \mathrm{E}-02)$ & (8.22E-04) & (1.31E-02) & (1.99E-03) & (3.95E-04) & (2.93E-04) & (1.50E-02) & (1.14E-02) & $(4.16 \mathrm{E}-06)$ & $(4.23 \mathrm{E}-02)$ & $(9.26 \mathrm{E}-02)$ & $(4.05 \mathrm{E}-02)$ \\
\hline \multirow[t]{2}{*}{$\phi$} & 0.70314 & 0.06073 & 0.24332 & 0.17088 & 0.01231 & 0.34471 & 0.36434 & 0.27334 & 0.725489 & 0.669309 & 0.025909 & 0.21847 \\
\hline & (8.61E-02) & (1.36E-02) & (1.08E-02) & (5.40E-03) & (8.74E-03) & (2.43E-02) & (4.30E-02) & (1.67E-02) & $(3.85 \mathrm{E}-02)$ & (5.15E-02) & (1.09E-01) & (8.81E-02) \\
\hline \multicolumn{13}{|c|}{ Short-run } \\
\hline \multirow[t]{2}{*}{$\alpha$} & 0.00479 & 0.84766 & 0.30551 & 0.06395 & 0.76808 & 0.27616 & 0.14518 & 0.26419 & 0.059710 & 0.042250 & 0.693534 & 0.43923 \\
\hline & $(2.44 \mathrm{E}-02)$ & (5.89E-03) & (3.78E-03) & $(4.04 \mathrm{E}-03)$ & (1.64E-02) & $(3.06 \mathrm{E}-02)$ & $(2.74 \mathrm{E}-02)$ & $(1.23 \mathrm{E}-03)$ & $(2.55 \mathrm{E}-02)$ & (2.23E-02) & (1.46E-01) & (8.89E-02) \\
\hline \multirow[t]{2}{*}{$\gamma$} & 0.07657 & -0.06539 & -0.01786 & -0.09496 & -0.03854 & -0.15696 & -0.10888 & -0.02364 & & -0.161387 & -0.253898 & -0.46600 \\
\hline & (3.58E-02) & (7.31E-03) & (1.36E-03) & (5.17E-03) & (1.53E-02) & $(2.54 \mathrm{E}-02)$ & $(2.57 \mathrm{E}-02)$ & (4.69E-03) & & $(4.13 \mathrm{E}-02)$ & (1.24E-01) & (1.09E-01) \\
\hline \multirow[t]{2}{*}{$\beta$} & 0.01659 & 0.08686 & 0.69530 & 0.94499 & 0.22564 & 0.72050 & 0.81075 & 0.73849 & 0.764372 & 0.188431 & 0.066618 & 0.45440 \\
\hline & $(2.08 \mathrm{E}-01)$ & $(1.23 \mathrm{E}-02)$ & (4.03E-03) & $(4.01 \mathrm{E}-03)$ & $(1.76 \mathrm{E}-02)$ & (3.29E-02) & $(2.96 \mathrm{E}-02)$ & (5.80E-04) & $(8.12 \mathrm{E}-02)$ & (2.10E-01) & (1.05E-01) & $(1.34 \mathrm{E}-01)$ \\
\hline
\end{tabular}

* as stated above the SD market starts on 31/03/2004

Tab. 2b - Model \& Efficiency Statistics

\begin{tabular}{|c|c|c|c|c|c|c|c|c|c|c|c|c|}
\hline \multirow{2}{*}{$\begin{array}{l}\text { Period } \\
\text { Market }\end{array}$} & \multicolumn{4}{|c|}{ Pre-earthquake 31/12/1997-10/03/2011 } & \multicolumn{4}{|c|}{ Post-earthquake 11/03/2011-31/12/2016 } & \multicolumn{4}{|c|}{$\begin{array}{l}\text { Immediate post-earthquake } \\
11 / 03 / 2011-31 / 12 / 2012\end{array}$} \\
\hline & $\mathrm{SD}^{*}$ & $\mathrm{FX}$ & Equity & Gold & SD & $\mathrm{FX}$ & Equity & Gold & SD & $\mathrm{FX}$ & Equity & Gold \\
\hline Distribution & Student $t$ & Normal & Normal & Normal & GED & Student $\mathrm{t}$ & GED & Normal & Normal & Normal & GED & Student $t$ \\
\hline \multicolumn{13}{|l|}{ Model Statistics } \\
\hline $\begin{array}{l}\text { Log Likeli- } \\
\text { hood }\end{array}$ & 5481.58 & 11927.59 & 17324.28 & 13384.73 & 7035.21 & 3126.35 & 8296.20 & 6188.23 & 2567.06 & 1024.25 & 2412.41 & 2367.83 \\
\hline $\mathrm{R}^{2}$ & 0.97375 & 0.96465 & 0.97206 & 0.96844 & 0.96206 & 0.96898 & 0.976416 & 0.96290 & 0.967524 & 0.975243 & 0.967972 & 0.973087 \\
\hline DW-Statistics & 1.17338 & 1.17330 & 1.32401 & 1.23932 & 1.32937 & 1.33019 & 1.598708 & 1.25387 & 1.319636 & 1.624259 & 1.215740 & 1.472661 \\
\hline ARCH effect & 0.27556 & 0.08292 & 0.48004 & 23.79750 & 0.09492 & 0.266881 & 0.001440 & 0.00020 & 0.388106 & 0.194276 & 0.009925 & 0.164884 \\
\hline Jarque-Bera & 11850.00 & 107753.90 & 18235.74 & 30252.50 & 7272.04 & 43526.78 & $6.15 \mathrm{E}+07$ & 2102.99 & 1730.49 & 690.05 & 574.32 & 5026.56 \\
\hline$\sigma^{2}$ & 0.543742 & 0.022040 & 0.054824 & 0.160836 & 0.073001 & 0.014122 & 0.080047 & 0.478577 & 0.017851 & 0.012019 & 0.046360 & 0.339255 \\
\hline \multicolumn{13}{|l|}{ EMH Test } \\
\hline Long-run & & & & & & & & & & & & \\
\hline
\end{tabular}




\begin{tabular}{|l|l|l|l|l|l|l|l|l|l|l|l|l|l|l|l|l|}
\hline $\begin{array}{l}\text { EMH } \\
\text { Statistic }\end{array}$ & 1.27878 & 2.67432 & 1.64809 & 0.80042 & 0.17155 & 24.40540 & 4.47396 & 0.39725 & 33.35062 & 18.69107 & 4.84573 & 0.54012 & \\
\hline Efficiency & Accept & Reject & Accept & Accept & Accept & Reject & Reject & Accept & Reject & Reject & Reject & Accept \\
\hline Short-run
\end{tabular}

* as stated above the SD market starts on 31/03/2004

In the short run, the $\beta$ coefficients all point to a low market persistent contrasting with the long run. However, the SD market once again seem to be displaying an interesting $\beta$ coefficient with a significantly low statistic. Thus, hinting at a very low volatility persistent in the aftermath of a shock to the SD market. The contrastingly high $\alpha$ coefficients for the shocks to the market in all four markets would suggest highly reactive market participants to shocks in the market. The standout market is once again the SD market with a very high market shock coefficient. The $\gamma$ coefficient is hinting at the Japanese market being dominated by leverage effects. However, like all observed coefficients in this period, the SD market is significant in that it is hinting at a close to zero asymmetrical effect. The significant of that is not that it is approaching zero but rather that it highlights the different impact on the SD market in the short run in comparison with the other markets when considered with the other coefficients.

Not surprisingly given the indications of volatile markets, Table 2 hints at a very mixed picture with respect to the efficiency of the Japanese financial market in the aftermath of the Tohoku earthquake. The SD and Gold markets again hint at an acceptance of the efficient market hypothesis, whereas the FX market points to an unchanged acceptance of the null hypothesis of the market being too volatile to be efficient. The "cat amongst the pigeons" is the equity market where there is a split with the long run accepting whereas the short run is rejecting the null hypothesis of the market being too volatile to be efficient. This raises an issue in that it is assumed that the financial market is efficient in the long run and inefficient in the short run. As suggested by De Bondt (2000), the price tends to deviate from the fundamental value in the short run and revert to the fundamental value in the long run. However, what we are observing here is the opposite.

It is worth noting as highlighted earlier, this period of observation saw a number of external factors playing a major role in the behaviour of market participants in the Japanese financial market. As hinted earlier, these factors on their own would have induced a high amount of uncertainty. However, we think that the earthquake increased the uncertainty and as hinted by standard risk aversion (Kimball, 1993; Diamond \& Stiglitz, 1974), the market participants became increasingly risk averse. At the same time, the FX, sovereign debt and especially the Gold markets were experiencing a flight from the US and Eurozone to the safe part of the Japanese markets. And as hinted earlier, in a market where the reactions cancel each other out, the stability status means the market could give the appearance of an efficient market. The issue is that the sovereign debt and Gold markets accepted this argument, whereas the FX market rejected it. This may be because the pull of one factor was overwhelming i.e. the reaction of the market participants was strong enough to tip the scales. 
At first sight, the equity market may appear to be strange in that it is going against the theory. Remember as hinted by De Bondt (2000), in theory the market should reflect an efficient market in the long run and a volatile market in the short run. However, it seems that the equity market accepts the stability argument in the short run as highlighted in the previous paragraph. The reactions to the external factors by the market participants cancelled each other out, thus given the appearance of an efficient market. Furthermore, it must be noted that the equity market is also governed by internal factors such as information on the profitability and an organisational structure of the constituent corporations of the index. Since the long run is about the strategic planning of the constituent corporations as well as the stability of the Japanese economy and state. A possible explanation is that the long-term stability or more accurately instability of the Japanese economy and state due to a weakened economy and a strong competition from China, when added to the problems in the strategic planning and increasingly vague information of Japanese corporations, gave raise to increased uncertainty in the equity market in the long run which translated itself to a highly volatile market.

\subsection{Immediate Post-Earthquake Period}

The results from Table 2 confirm with respect to the immediate post-earthquake period to be hinting at a very volatile market. As suggested earlier in the article, the Japanese economy suffered a double hit, not only did the earthquake damage economic output but also after such a devastating natural disaster, the cost in re-building the country would likely cost billions, if not trillions, and take a long time. In the aftermath of crisis be it a natural disaster or financial meltdown market participants become increasingly reactive and risk averse as the little information which was conflicting and frequently updated. The real issue is that nobody really knows what is happening, leading to asymmetrical information.

In the long run, the Japanese financial market was split with both the SD and FX markets showing signs of being persistent and highly reactive to market shocks with high $\varrho$ and $\phi$ coefficients respectively. Surprisingly, the equity market seems to be indicating low $\varrho$ and $\phi$ coefficients illustrating that the market participants were indifferent about the impact on the pricing of the constituent organisations in the Nikkei 225 index. In truth, the majority of these corporations were not hugely affected in the long run.

The short run observation also paints a split picture with the SD and FX markets showing signs of not being affected. Both have a significantly low $\alpha$ coefficient, thus meaning market participants were not reactive to the events. And while the equity market does illustrate a high reaction to market shocks, yet as with the FX and SD markets, this is not reflected in the $\beta$ coefficient hinting at a significantly low market persistent level. Due to estimation errors, we could not estimate the $\gamma$ coefficient for the SD market. However, the $\gamma$ coefficient for the FX and equity markets highlight a significant leverage effect.

As suspected, Table 2 shows that the impact from the Tohoku earthquake in the immediate aftermath on all three observed markets was to make the Japanese financial market too volatile to be efficient. The statistics points to a shift in the SD and Equity markets from accepting the EMH to accepting the null hypothesis. However, to a certain extent, the FX market remained unchanged. And while this is true, yet the damming fact lays in the EMH statistics the shift be- 
tween the pre-earthquake and immediate aftermath observational periods is tellingly significant. This shift in the EMH statistics means that the market had a significant uplift in volatility in the immediate aftermath.

A possible explanation could be found in the way market participants generally react when faced with such huge systematic risk and a failure of the information system. Under these conditions, acknowledged as Knightian uncertainty, market participants becoming increasingly risk averse and as markets' prices go down in the short term, this turns to a loss aversion. As we have seen earlier, the standard risk aversion dictates that market participants become increasingly risk averse after bearing one loss. The often limited and conflicting information lead to a failure in the information system leading to market participants reacting to any information. As we saw in the recent financial and sovereign debt crises, when this is combined with Knightian uncertainty; the market becomes increasingly volatile and reactive leading to flights to safety.

\section{CONCLUSION}

In this article, we used the C-GARCH-t variant of the variance bound test proposed by Fakhry \& Richter (2018) to distinguish the long and short run effects of the Tohoku earthquake on the efficiency of the Japanese financial market. The results suggest that the impact did shift the market in the immediate aftermath of the event. However, in the longer term, other events may have played a bigger part in the pricing of market. The results seem to indicate that the Japanese financial market could be in parts efficient, however, a partly efficient market is basically an inefficient market.

The evidence from the literature and our empirical evidence seems to be pointing at the impact from the Tohoku earthquake on the financial market being short lived. Therefore, backing one of the key arguments in the behavioural finance theory, as hinted by De Bondt (2000) market participants sometimes overreact heavily at the initial stages of an event. Thus, leading to a correction during the next period. This highlights that the Japanese financial markets were not efficiently pricing the information on the Tohoku earthquake. Like any crisis, in the immediate time horizon, market participants tend to act on little and often conflicting information leading to asymmetrical information and/or a failure in the information system which is reflected in the inefficient pricing of the markets.

At the heart of the impact of the Tohoku earthquake on the Japanese financial markets lays the familiar problem of conflicting/limited information during a crisis or event inducing an extreme environment. The key word here being information, the problem is that during any crisis or extreme event and especially a sudden event such as the Tohoku earthquake; information or news is extremely unreliable, limited and constantly changing. However, market participants are essentially humans and hence reactive in the immediate aftermath of any event or crisis. The key is the information that filters after the immediate aftermath, the official statements and statistics, these need to be collated and not conflicting, if the markets are to regain any sort of normality and trust in the information. 


\section{References}

1. Abbas, S. A. (2018). Entrepreneurship and information technology businesses in economic crisis. Entrepreneurship and Sustainability Issues, 5(3), 682-692. https://doi.org/10.9770/ jesi.2018.5.3(20).

2. Ahmed, A., Ali, R., Ejaz, A., \& Ahmad, M. I. (2018). Sectoral integration and investment diversification opportunities: evidence from Colombo Stock Exchange. Entrepreneurship and Sustainability Issues, 5(3), 514-527. https://doi.org/10.9770/jesi.2018.5.3(8).

3. Asongu, S. A. (2012). The 2011 Japanese earthquake, tsunami and nuclear crisis: Evidence of contagion from international financial markets. Journal of Financial Economic Policy, 4(4), 340-353, https://doi.org/10.1108/17576381211279307

4. Barton, D. R. (2005). How Is the Stock Market Affected by Natural Disasters? http://www. investmentu.com/how-the-stock-market-is-affect-by-natural-distasters.html [Accessed Date 23 February 2018].

5. Black, F. (1976). Studies of Stock Market Volatility Changes. Proceedings of the Business and Economic Statistics Section. American Statistical Association, 177-181.

6. Clemente, P. (2011). Tohoku Earthquake of March 11th, 2001. http://www.enea. it/it/internazionali/relazioni-internazionali/eventi-internazionali/enea-in-japan-2011/ earthquake-engineering/clemente.pdf [Accessed Date 20 February 2018].

7. De Bondt, W. (2000). The Psychology of Underreaction and Overreaction in World Equity Markets. in D.B. Keim and W.T. Ziemba (ed.) Security Market Imperfections in World Wide Equity Markets, Cambridge: Cambridge University Press), 65-69.

8. Engle, R. F. \& Patton, A. J. (2001). What Good is a Volatility Model? Quantitative Finance, 1(2), 237-245. https://doi.org/10.1088/1469-7688/1/2/305.

9. Engle, R. F. \& Lee, G., (1999). A Long-run and Short-run Component Model of Stock Return Volatility. In: Engle, R.F., White, H. (ed.) Cointegration, Causality and Forecasting-A Festschrift in Honour of Clive W. J. Granger, Oxford: Oxford University Press.

10. Fakhry, B. (2016). A Literature Review of the Efficient Market Hypothesis. Turkish Economic Review, 3(3), 431-442. https://doi.org/10.1453/ter.v3i3.928.

11. Fakhry, B. \& Richter, C. (2016). Testing the Efficiency of the Sovereign Debt Market using an Asymmetrical Volatility Test. Journal of Management and Training for Industries, 3(2), 1-15.

12. Fakhry, B. \& Richter, C. (2018). Does the Federal Constitutional Court Ruling mean the German Financial Market is Efficient? German University in Cairo, Working Paper 46.

13. Fakhry, B., Masood, O. \& Bellalah, M. (2017). Are the GIPS sovereign debt markets efficient during a crisis? Journal of Risk, 19(S1), pp. S27-S39. https://doi.org/10.21314/ JOR.2017.373.

14. Fama, E. F. (1965). Random Walks in Stock Market Prices. Financial Analyst Journal, 21(5), 55-59. https://doi.org/10.2469/faj.v51.n1.1861.

15. Fernández, A., Hernández, A., Hernández, M., \& Chicaiza, O. (2018). Savings and credit cooperatives in Pichincha, Ecuador: is this a sustainable social management case? Journal of Security and Sustainability Issues, 7(3), 549-558. https://doi.org/10.9770/jssi.2018.7.3(14). 
16. Ferreira, S. \& Karali, B. (2015). Do Earthquakes Shake Stock Markets? PloS ONE, 10(7), 1-19. https://doi.org/10.1371/journal.pone.0133319.

17. Hanari, D. (2013). Japan's Economy: from the "lost decade" to Abenomics. House of Common Library, Standard Note: SN06629.

18. Hoshi, T. \& Kashyap, A. K. (2014). Japan's Financial Crisis and Economic Stagnation. The Journal of Economic Perspectives, 18(1), 3-26.

19. Jankelová, N., Jankurová, A., Beňová, M., \& Skorková, Z. (2018). Security of the business organizations as a result of the economic crisis. Entrepreneurship and Sustainability Issues, 5(3), 659-671. https://doi.org/10.9770/jesi.2018.5.3(18).

20. Kawai, M., \& Takagi, S. (2009). Why was Japan hit so hard by the global financial crisis? Asian Development Bank Institute, ADBI Working Paper No. 153.

21. Lay, T. \& Kanamori, H. (2011). Insights from the great 2011 Japan earthquake. Physics Today, 64(12), 33-39. https://doi.org/10.1063/PT.3.1361.

22. Lee, W. Y., Jang, C. X. \& Indro, D. C. (2002). Stock Market Volatility, Excess Returns and the Role of Investor Sentiment. Journal of Banking \& Finance, 26(12), 2277-2299. https://doi. org/10.1016/S0378-4266(01)00202-3.

23. Luo, N. (2012). The Impact of Natural Disasters on Global Stock Market: the Case of the Japanese 2011 Earthquake. http://library2.smu.ca/handle/01/24714\#.WWYR_YjysuU [Accessed Date 19 February 2018].

24. Maierhofer, S. (2011). 5 worst Disasters - How did the Stock Market React? http://www. nasdaq.com/article/5-worst-disasters-how-did-the-stock-market-react-cm68124 [Accessed Date 15 February 2018].

25. Malkiel, B. G. (1962). Expectations, Bond Prices, and the Term Structure of Interest Rates. The Quarterly Journal of Economics, 76(2), 197-218. https://doi.org/10.2307/1880816.

26. Masood, O., Aktan, B., Gavurová, B., Fakhry, B., Tvaronavičienė, M., \& MartinkutéKaulienè, R. (2017). The impact of regime-switching behaviour of price volatility on efficiency of the US sovereign debt market. Economic Research-Ekonomska Istraživanja, 30(1), 1865-1881. http://dx.doi.org/10.1080/1331677X.2017.1394896.

27. Mentel, G., Szetela, B., \& Tvaronavičienè, M. (2016). Qualifications of managers vs. effectiveness of investment funds in Poland. Economics \& Sociology, 9(2), 126-137. http:// dx.doi.org/10.14254/2071-789X.2016/9-2/8.

28. Michailova, J., Mačiulis, A., \& Tvaronavičienė, M. (2017). Overconfidence, risk aversion and individual financial decisions in experimental asset markets. Economic researchEkonomska istraživanja, 30, 1, 1119-1131. http://dx.doi.org/10.1080/1331677X.2017.1311234.

29. Mimura, N., Yasuhara, K., Kawagoe, S., Yokoki, H., \& Kazama, S. (2011). Damage from the Great East Japan Earthquake and Tsunami - A quick report. Mitigation and Adaptation Strategies for Global Change, 16(7), 803-818. https://doi.org/10.1007/s11027-011-9297-7.

30. Mori, N., Takahashi, T., Yasuda, T. \& Yanagisawa, H. (2011). Survey of 2011 Tohoku earthquake tsunami inundation and run-up. Geophysical Research Letters, 38(7), 1-7. https:// doi.org/10.1029/2011GL048689. 
31. Nakaso, H. (2001). The Financial Crisis in Japan during the 1990s: how the Bank of Japan Responded and the Lessons Learnt. Bank for International Settlements, BIS Paper No. 6.

32. Parker, M. \& Steenkamp, D. (2012). The economic impact of the Canterbury earthquakes. Reserve Bank of New Zealand Bulletin, 70(3), 13-25.

33. Pastor, L. \& Stambaugh, R. F. (2012). Are Stocks Really Less Volatile in the Long Run? The Journal of Finance, 67(2), 431-478. https://doi.org/10.1111/j.1540-6261.2012.01722.x.

34. Peker, S., Aktan, B., \& Tvaronavičienè, M. (2017). Clustering in key G-7 stock market indices: an innovative approach. Marketing and Management of Innovations, No. 1, 300-310, http://dx.doi.org/10.21272/mmi.2017.1-27.

35. Sato, M., Ishikawa, T., Ujihara, N., Yoshida, S., Fujita, M., Mochizuki, M. \& Asada, A. (2011). Displacement Above the Hypocenter of the 2011 Tohoku-Oki Earthquake. Science, 332(6036), 1395, https://doi.org/10.1126/science.1207401.

36. Shiller, R. J. (1979). The Volatility of Long-Term Interest Rates and Expectations Models of the Term Structure. The Journal of Political Economy, 87(6), 1190-1219. https://doi. org $/ 10.1086 / 260832$.

37. Shiller, R. J. (1981). The Use of Volatility Measures in Assessing Market Efficiency. The Journal of Finance, 36(2), 291-304. https://doi.org/10.1111/j.1540-6261.1981.tb00441.x.

38. Statman, M. (2008). What is Behavioral Finance? in F. J. Fabozzi (ed.) The Handbook of Finance II, Hoboken (New Jersey): John Wiley \& Sons), 79-84.

39. Subrahmanyam, A. (2007). Behavioural Finance: A Review and Synthesis. European Financial Management, 14(1), 12-29. https://doi.org/10.1111/j.1468-036X.2007.00415.x.

40. Szturo, M., Włodarczyk, B., Ionescu, G. H., Firoiu, D., Pirvu, R., \& Badircea, R. (2018). The impact of credit availability on small and medium companies. Entrepreneurship and Sustainability Issues, 5(3), 565-580. https://doi.org/10.9770/jesi.2018.5.3(12).

41. Tvaronavičienè, M. (2018). Toward efficient policy making: forecasts of vulnerability to external global threats. Journal of Security and Sustainability Issues 7(3): 591-600. https://doi. org/10.9770/jssi.2018.7.3(18).

42. Veselovsky, M. Y., Pogodina, T. V., Ilyukhina, R. V., Sigunova, T. A., \& Kuzovleva, N. F. (2018). Financial and economic mechanisms of promoting innovative activity in the context of the digital economy formation. Entrepreneurship and Sustainability Issues, 5(3), 672681. https://doi.org/10.9770/jesi.2018.5.3(19).

43. Wang, L. (2011). The Impact of Japanese Natural Disasters on Stock Market. Retrieved from http://artsci.wustl.edu/ gradconf/LinWang.pdf.

44. Worthington, A. C. (2008). The impact of natural events and disasters on the Australian stock market: A GARCH-M analysis of storms, floods, cyclones, earthquakes and bushfires. Global business and Economics Review, 10(1), 1-10. https://doi.org/10.1504/ GBER.2008.016824.

45. Worthington, A. C., \& Valadkhani, A. (2004). Measuring the impact of natural disasters on capital markets: an empirical application using intervention analysis. Applied Economics, 36(19), 2177-2186. https://doi.org/10.1080/0003684042000282489. 
46. Zemlickiene, V., Mačiulis, A., \& Tvaronavičienè, M. (2017). Factors impacting the commercial potential of technologies: expert approach. Technological and Economic Development of Economy, 23(2), 410-427. http://dx.doi.org/10.3846/20294913.2016.1271061.

\section{Contact information}

prof. Ing. Bachar Fakhry, Ph.D.

The University of Lahore

School of Accountancy and Finance

Pakistan

E-mail:mbachar.fakhry@me.com

prof. Ing. Bora Aktan, Ph.D.

University of Babrain

College of Business Administration

Babrain

E-mail:gbora@uob.edu.bb

ORCID: bttps://orcid.org/0000-0002-1334-3542

prof. Ing. Omar Masood, Ph.D.

The University of Labore

School of Accountancy and Finance

Pakistan

E-mail:masood_omar@hotmail.com

prof. dr. Manuela Tvaronavičiene, Ph.D.

Vilnius Gediminas Technical University

Lithuania

E-mail:manuela.tvaronaviciene@vgtu.lt

ORCID: bttp://orcid.org/0000-0002-9667-3730

prof. Ing. Saban Celik, Ph.D.

Katip Celebi University

Faculty of Economics and Administrative Sciences

Department of Business Administration

Turkey

E-mail:saban.celik@ikc.edu.tr

ORCID: bttps://orcid.org/0000-0002-4918-4598 